\title{
Pengembangan desain tas wanita berbahan rumput Purun menggunakan metode ATUMICS
}

\author{
Widya Christa Turang, ${ }^{1 *}$ Daniel Alexander Octavianus Turang ${ }^{2}$ \\ ${ }^{1}$ Jurusan Desain Produk Universitas Kristen Duta Wacana Yogyakarta, Yogyakarta, Indonesia \\ ${ }^{2}$ Program Studi Teknik Informatika, Sekolah Tinggi Teknologi Bontang, Bontang, Indonesia
}

\begin{abstract}
Purun is a wild plant that can be found in Kalimantan. Purun is used as material for making traditional handicraft products. Utilization of Purun is currently not favored in demand by the general public, because the design of Purun handicraft products is not yet fully developed so that it didn't get enough attention in the community. This study was conducted using the ATUMICS method with a rapid ethnographic approach and observation technique to support the data collection process and interview technique to explore the depth of the data. The purpose of this research is to develop designs from Purun-made products to increase the selling value of Purun-made products. Based on research that has been done, the design of Purunmade products will focus on women's fashion products in the form of women's bags. Women's handbag products are one of the pioneers of fashion that always grab women's attention.
\end{abstract}

Key words: women's fashion, bags, Purun, ATUMICS, ethnography

\begin{abstract}
Abstrak
Purun merupakan tumbuhan liar yang dapat di Kalimantan. Purun dimanfaatkan sebagai bahan pembuatan produk kerajinan tradisional. Pemanfaatan Purun saat ini kurang diminati oleh masyarakat umum dikarenakan desain dari produk kerajinan Purun tidak berkembang sehingga kurang mendapat perhatian di tengah masyarakat. Penelitian dilakukan dengan menggunakan metode ATUMICS dengan pendekatan rapid etnografi dan pengumpulan data menggunakan teknik observasi serta wawancara untuk menggali kedalaman data. Tujuan dari penelitian yaitu untuk mengembangkan desain dari produk berbahan Purun untuk meningkatkan nilai jual dari produk berbahan Purun. Berdasarkan riset yang telah dilakukan, maka desain produk berbahan Purun akan difokuskan menjadi produk fashion wanita berupa tas wanita. Produk tas wanita merupakan salah satu penunjang fashion yang tidak luput dari perhatian wanita.
\end{abstract}

Kata kunci: mode wanita, tas, Purun, ATUMICS, etnografi

\section{Pendahuluan}

Di Kalimantan Tengah, khususnya di kabupaten Kapuas, terdapat tanaman yang tumbuh liar di dekat air atau rawa gambut yaitu Purun. Purun adalah tanaman khas daerah rawa yang memiliki batang tegak, tidak bercabang, memiliki ruas, dan berwarna hijau mengkilat. Tanaman ini memiliki serat yang teksturnya cukup kuat. Kekuatan terkstur Purun, maka masyarakat memanfaatkannya sebagai bahan pembuatan kerajinan tangan tradisional.

Desa Bunga Mawar yang terdapat di Kabupaten Kapuas Kalimantan Tengah merupakan salah satu desa yang memanfaatkan serat Purun sebagai bahan pembuatan produk tradisional. Selain menjadi petani, di desa ini hampir semua masyarakatnya mampu membuat kerajinan tradisional dari bahan Purun, tidak sedikit pula yang ahli sehingga menggantungkan hidupnya dari hasil menjual kerajinan Purun.

Pemanfaatan Purun menjadi produk kerajinan tradisional dikerjakan oleh para pengrajin yang tinggal di Desa Bunga Mawar. Meskipun di desa tersebut ada beberapa pengrajin dengan usia antara 38-60 tahun, namun mayoritas pengrajin di desa tersebut adalah pengrajin lanjut usia. Hal ini menjadi salah satu faktor terbatasnya pengembangan desain dari produk tradisional berbahan Purun.

\footnotetext{
* Corresponding author Tel : +62-896-9222-8022 ; e-mail : widyachristaturang@gmail.com
} 
Kerajinan tradisional yang diproduksi oleh pengrajin Desa Bunga Mawar diantaranya tikar, bakul, topi, dan nampan. Pemanfaatan Purun saat ini kurang diminati oleh masyarakat umum dikarenakan desain dari produk kerajinan Purun tidak berkembang sehingga kurang mendapat perhatian di tengah masyarakat.

Saat ini, desain suatu produk mampu berpengaruh pada gaya fashion seseorang. Fashion merupakan bagian terpenting ditengah antusias masyarakat luas untuk pembaruan inovasi. Di era modern saat ini, perkembangan fashion memang berkembang sangat pesat dan berpengaruh pada banyak aspek dalam keseharian masyarakat. Setiap orang dapat memilih fashion sesuai dengan kepribadiannya, mulai dari pakaian, aksesoris, sepatu hingga tas yang digunakan.

Sebagai salah satu sarana membawa, tas saat ini tidak luput pula dari perhatian dalam tren fashion. Tas merupakan salah satu benda yang digunakan semua kalangan dan segala usia. Selain memiliki fungsi sebagai wadah menaruh dan membawa barang saat bepergian, saat ini tas juga berfungsi sebagai aksesoris fashion penunjang penampilan, terutama untuk kalangan anak muda.

Perkembangan desain pada tas kini semakin menarik. Para wanita khususnya dikalangan muda menganggap sebuah tas mampu meningkatkan kepercayaan diri dan membuatnya terlihat lebih fashionable. Dilihat dari gaya hidup modern masyarakat saat ini, para wanita muda lebih cenderung menggunakan tas yang diproduksi menggunakan mesin pabrik dibandingkan dengan tas hasil kerajinan tangan berbahan alami. Tas berbahan alami hasil kerajinan tangan dinilai kurang mampu menunjang penampilan.

Dengan pengembangan desain dari kerajinan tradisional Purun dalam sebuah tas, produk kerajinan tangan berbahan Purun ini mampu menjadi salah satu pelopor perkembangan produk kerajinan berbahan Purun. Dengan demikian, produk kerajinan berbahan Purun dapat lebih dikenal serta diminati masyarakat terutama para wanita muda.

\section{Bahan dan metode}

Purun adalah tumbuhan liar yang dapat beradaptasi dengan baik di air atau rawa pasang surut. Di lahan rawa Kalimantan, Purun juga berfungsi sebagai inang alternatif hama dan tempat berlindung atau habitat musuh alami, serta sebagai biopestisida, biofilter, biofertilizer, dan bahan obat tradisional (Budiman, Thamrin, \& Asikin, 1988).
Purun merupakan tanaman perangkap bagi penggerek batang padi putih dan habitat beberapa jenis musuh alami, seperti predator dan parasitoid (Asikin, Thamrin, \& Budiman, 2001). Fungsi lain Purun, yaitu sebagai sumber bahan organik dan biofilter yang mampu menyerap unsur beracun atau logam berat seperti besi $(\mathrm{Fe})$, sulfur $(\mathrm{S})$, merkuri $(\mathrm{Hg})$, timbal $(\mathrm{Pb})$, dan kadmium $(\mathrm{Cd})$ (Asikin \& Thamrin 2011). Purun masuk dalam divisi Spermatophyta, subdivisi Angiospermae, kelas Monocotyledonese, ordo Cyperales, famili Cyperaceae, genus Eleocharis, dan spesies Eleocharis dulcis (Van Steenis, 2003).

Purun dapat tumbuh sepanjang tahun, terutama pada lahan yang selalu berair, seperti tepi sungai dan saluran tersier. Purun adalah jenis rumput yang tumbuh pada lahan marginal yang tergenang air (Brecht, 1998), seperti yang terlihat pada Gambar 1. Tumbuhan ini mempunyai rimpang pendek dengan stolon memanjang berujung bulat gepeng, berwarna kecoklatan sampai hitam. Batang tegak, tidak bercabang, berwarna keabuan hingga hijau mengilap dengan panjang 50-200 $\mathrm{cm}$ dan tebal 2-8 $\mathrm{mm}$. Daun Purun mereduksi menjadi pelepah yang berbentuk buluh, seperti membran yang menyelubungi pangkal batang, kadang-kadang dengan helaian daun rudimeter, ujung daun tidak simetris, berwarna coklat kemerahan sampai lembayung, dan tanpa lidah daun. Bunganya bulir majemuk, terletak pada ujung batang dengan panjang 2-6 $\mathrm{cm}$ dan lebar 3-6 $\mathrm{mm}$, terdiri atas banyak buliran berbentuk silinder, bersifat hermafrodit. Buah berbentuk bulat telur sungsang, berwarna kuning mengilap sampai coklat. Bentuk buah Purun dapat dilihat pada Gambar 2. Purun dapat ditemukan di daerah terbuka di lahan rawa yang tergenang air, pada ketinggian $0-1.350 \mathrm{~m}$ di atas permukaan laut. Tumbuhan ini juga banyak ditemui di daerah persawahan dan tergenang air. Sebelum Purun dimanfaatkan, biasanya Purun dijemur terlebih dahulu, seperti yang terlihat pada Gambar 3 .

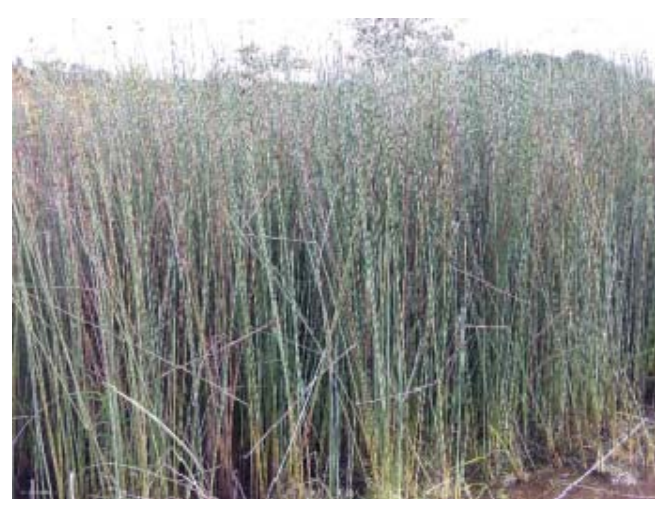

Gambar 1. Tumbuhan Purun 


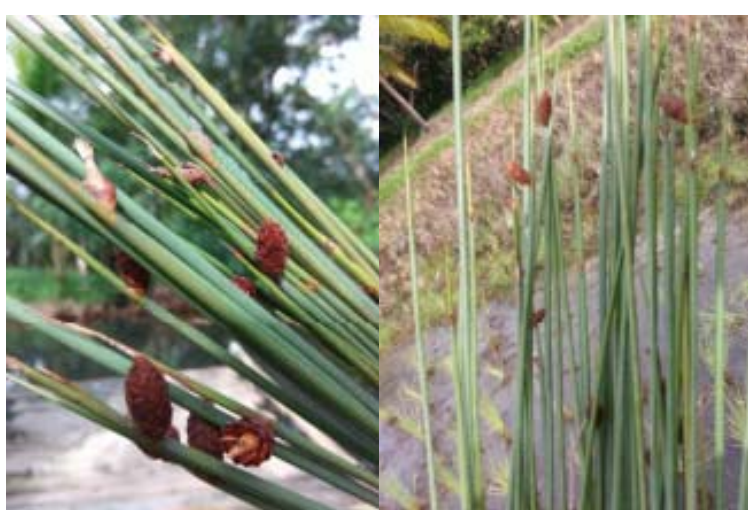

Gambar 2. Buah rumput Purun

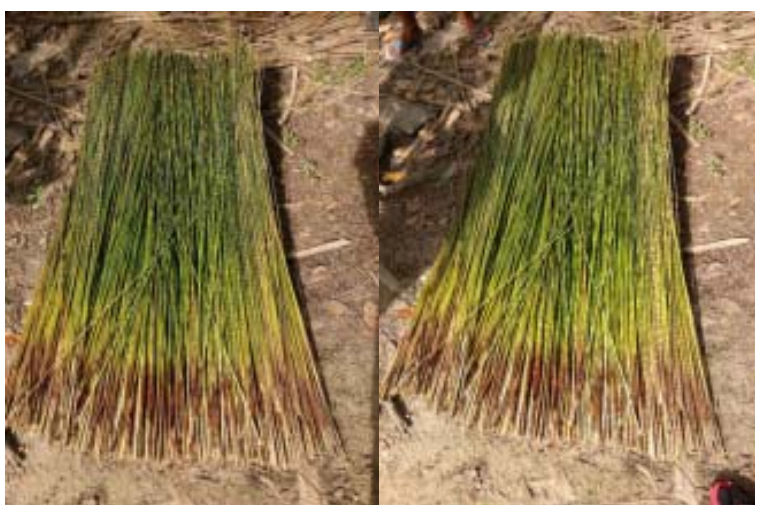

Gambar 3. Purun dijemur

\section{Teknik anyam}

Anyaman merupakan hasil pekerjaan menganyam, adapun menganyam berarti menyilang-nyilang lembaran pita lidi atau bahan lainnya secara teratur dan berulang-ulang (Wihardi, 1979). Anyaman adalah barang yang dianyam. Jadi pengertiannya bahwa benda-benda serta barang-barang, dapat disebut sebagai hasil melalui proses anyaman (Zain, 1992).

Menganyam merupakan perkerjaan menjalin pitapita dari berbagai bahan yang disusun menurut dua, tiga, dan empat arah sehingga membentuk benda berdimensi tiga maupun berdimensi dua (Shaifuddin, 2009). Prinsip menganyam adalah menyusupkan dan menumpangkan pita atau serat ke pita atau serat lainnya yang berbeda arah. Kegiatan menganyam juga dapat diartikan sebagai proses menjaringkan dan meyilangkan bahan-bahan tumbuh-tumbuhan untuk dijadikan satu rumpun yang kuat dan dapat dipergunakan untuk keperluan sehari-hari (Raharjo, 2011).

Anyaman adalah mengatur (bilah, daun pandan, dan sebagainya) tindih-menindih dan silangmenyilang (seperti membuat tikar, bakul) (KBBI, 2018). Menganyam adalah menyusun lungsi dan pakan (Gerbono \& Djarijah, 2005). Lungsi merupakan bagian anyam yang menjulur keatas (vertikal) dan pakan sebagai bagian anyam yang menjulur kesamping (horizontal) yang akan menyusup pada lungsi. Purun disebut lungsi dan pakan (Wahudi \& Darmowiyoto, 1979). Lungsi yaitu $\mathrm{pita} /$ daun anyaman tegak lurus terhadap si penganyam dan pita/daun anyaman berhadapan dengan si penganyam. Sedangkan pakan yaitu pita/daun anyaman yang disusupkan pada lungsi dan pita/daun anyaman yang dilintaskan pada lungsi. Berdasarkan uraian diatas dapat disimpulkan bahwa menganyam merupakan kegiatan menyusup dan menumpangkan lungsi \& pakan dari berbagai bahan untuk dijadikan satu rumpun yang kuat.

Teknik menganyam dapat dilakukan dengan beberapa cara yaitu sebagai berikut (Sumanto, 2005):

a. Menganyam dasar tunggal adalah cara pembuatan bentuk anyaman dua sumbu silang dengan menerapkan langkah anyaman satu-satu. Anyaman dasar tunggal disebut dengan motif anyam sasak atau enam warek. Ciri anyaman dasar tunggal ini adalah dengan menampilan jalinan bagian-bagian bahan anyaman berselang seling satu di atas satu di bawah secara bergantian sampai dihasilkan bentuk anyaman sesuai yang diinginkan.

b. Anyaman dasar ganda adalah cara pembuatan bentuk anyaman dua sumbu silang dengan menerapkan langkah anyaman dua-dua. Anyaman dasar ganda disebut dengan motif anyaman kepang. Ciri anyaman dasar ganda adalah menampilkan jalinan bagian-bagian bahan anyaman (pakan) berselang seling dua di atas dan dua di bawah secara bergantian pada bagian anyaman (lungsi) sampai dihasilkan bentuk anyaman sesuai yang diinginkan.

c. Anyaman dasar ganda dua adalah menganyam dua helailungsi dengan menumpang satu helai pakan. Tekniknya sama dengan anyaman tunggal tetapi jumlah lungsi sebanyak dua buah.

d. Anyaman dasar ganda tiga adalah teknik yang berasal dari pengembangan dari motif anyaman tunggal dan ganda, dengan teknik anyaman ganda tiga, setiap lungsi berjumlah tiga helai.

Berdasarkan tekniknya, anyaman dibagi menjadi dua, yaitu (Mutmainah, 2014): (1) Anyaman rapat, yaitu anyaman yang dibuat secara rapat; dan (2) Anyaman jarang, yaitu anyaman yang dibuat secara jarang (renggang).

\section{Metode pendekatan rapid etnografi}

Penelitian tentang tentang teknik anyam berbahan 
Purun menggunakan pendekatan rapid etnografi. Etnografi sebagai metode tertua dalam riset kualitatif sangat penting untuk penelitian-penelitian sosial yang mempunyai beberapa karakteristik yaitu: (1) menggali atau meneliti fenomena sosial, (2) data tidak terstruktur; (3) kasus atau sample sedikit; (4) dilakukan analisis data dan interpretasi data tentang arti dari tindakan manusia /'Human Action'. Hal ini sejalan dengan pendapat Brewer yang menempatkan etnografi sebagai salah satu prinsip metode penelitian ilmu sosial yang masuk kategori penelitian kualitatif. Dalam karyanya "Ethnography", Brewer mengungkapkan "The study of people in naturally occuring getting or 'fields' by means methods which capture their sosial meanings and ordinary activities, involving the reseacher participating directly in the setting if not also the activities, in order to collect data in a systematic manner but without meaning being imposed on the externally" (Brewer, 2000).

Data-data yang menyangkut penelitian ini diperoleh dari jurnal elektronik, pendekatan observasi dan wawancara untuk memperoleh data yang menyangkut tempat studi kasus. Selain itu, pencatatan lapangan dan dokumentasi juga menjadi penunjang informasi dalam pengumpulan data. Analisa serta pengolahan data menggunakan triangulasi data yaitu data literatur, observasi dan wawancara. Etnografi memiliki 12 teknik yang dalam dilakukan dalam riset, diantaranya sebagai berikut (Maulana, 2009):

\section{a. Participatory Observation}

Dalam teknik pengamatan yang bersifat aktif ini, ethnographer (orang yang melakukan riset etnografi) ikut bersama dalam melakukan kegiatan responden yang ditelitinya untuk memahami dengan lebih baik proses-proses yang terlibat didalamnya.

\section{b. Non-participatory Observation}

Dalam pengamatan pasif, ethnographer pada dasarnya hanya memperhatikan dan mencatat apa yang terjadi di hadapannya.

\section{c. Unstructured Interview}

Pada umumnya sebuah observasi dibarengi atau diikuti dengan proses wawancara yang tidak terlalu dipentingkan strukturnya. Wawancara ini bisa dilakukan sambil melihat perkembangan yang terjadi di lapangan secara langsung.

d. Contextual In-depth Interview

Teknik ini disebut juga dengan istilah "On-site Depth Interview". Pertanyaan yang disusun juga sudah lebih terstruktur karena ethnographer biasanya telah memperoleh informasi dan pengetahuan yang lebih baik dan luas tentang konsumen dan permasalahannya.

e. Shadowing/Day-in-the-Life
Digunakan untuk lebih memperoleh gambaran secara langsung seperti apa perilaku konsumen dan memperoleh jawaban dari latar belakang perilaku tersebut, seorang ethnographer meluangkan waktunya untuk tinggal bersama konsumennya dalam jangka waktu yang panjang.

f. Usability Interview

Wawancara yang lebih khusus lagi, yaitu yang merupakan gabungan antara observasi langsung dan wawancara untuk melihat proses pemakaian produk, disebut dengan "Usability Interview"

g. Story Telling

Tujuan "story telling" adalah menceritakan sebuah peristiwa dengan bahasa konsumen sendiri.

h. Netnography Ethnography

Teknik yang awalnya lebih menekankan pada faktor observasi langsung di lokasi asalnya, bisa difasilitasi dengan bantuan teknologi komunikasi dan internet sehingga muncul teknik-teknik baru.

i. Photography and Videography

Jika bisa memperoleh video tentang keidupan seorang konsumen, hal ini adalah sebuah kemewahan sendiri. Dalam organisasi, adakalanya sebagian orang tidak terlalu percaya akan insights yang ditemukan oleh orang lain, video dan foto ini menjadi sebuah senjata ampuh karena bisa menjelaskan secara komprehensif.

j. Creative Focus Group

Perbedaan utama antara teknik Creative Focus Group (CFG) dengan focus group umumnya adalah dari cara penyelenggaraan dan lokasinya.

k. Subject Diaries

Dengan membekali responden dengan sebuah buku harian, diharapkan responden akan lebih proaktif dalam mencatat kesehariannya dalam berinteraksi dengan produk.

1. Activity Sessions

Sesi eksplorasi ini bisa dilakukan dengan audiens yang berbeda-beda yang satu sama lain akan saling melengkapi

\section{Metode Transformasi ATUMICS}

Melestarikan budaya tradisi dapat dilakukan dengan mentransformasikan budaya tradisi ke dalam budaya modern (Nugraha, 2012). Salah satunya adalah dengan metode ATUMICS adalah singkatan dari Artefact, Technique, Utility, Material, Icon, Concept, Shape. Prinsip utama metode ATUMICS adalah tentang pengaturan, kombinasi, integrasi, atau campuran antara unsur-unsur dasar tradisi dengan modernitas. Metode ini digunakan untuk mengkombinasikan beberapa elemen budaya tradisi dengan beberapa elemen budaya modern dengan mempertahankan/menghilangkan dan menambahkan 
nilai berbeda hingga menjadi baru pada sebuah desain produk.

a. Artefact (A), mengacu pada suatu objek yang merupakan pusat dari penelitian ini, yaitu serat Purun.

b. Technique (T), teknik menjelaskan mengenai segala jenis pengetahuan teknik, seperti teknik pembuatan, teknik produksi, atau bagaimana akhirnya artefak terbentuk baik melalui proses, sejarah, maupun hal-hal lain yang mempengaruhinya. Teknik berarti juga teknologi, yang mengacu pada semua sarana dan proses dalam mewujudkan memanfaatkan potensi yang ada.

c. Utility (U), utilitas digunakan sebagai alat fungsional untuk suatu benda. Melihat dari pengertian semantik, utilitas atau fungsi memiliki dua pengertian yaitu dalam konteks kegunaan dan konteks produk/benda. Sebagai contoh anyam serat Purun, dalam kontek produk/benda maka serat Purun berfungsi sebagai bahan pembuatan kerajinan tradisional, dan dalam konteks kegunaan lainnya serat Purun yang dibuat dengan teknik anyam akan menunjukkan tingkatan dari nilai guna barang.

d. Material (M), istilah material mengacu pada setiap bentuk fisik dari hal-hal yang dapat dibuat. Dalam bidang arsitektur dan interior, pengertian biasanya ditekankan pada hasil akhir dari suatu objek benda/ produk, atau bangunan (kursi, meja, pintu, ukiran, dinding, lantai, dsb).

e. Icon (I), ikon dalam penelitian ini menunjuk kepada bentuk-bentuk simbolis yang mana dapat bersumber dari alam (flora dan fauna), geografi, ornamen, dekorasi, warna, mitos, orang, dan artefak. Peran elemen ikon adalah untuk memberikan tanda ikonik dan makna simbolik suatu benda.

f. Concept (C), pemahaman konsep mengacu pada faktor-faktor yang melatarbelakangi terbentuknya suatu objek. Konsep dapat diukur secara kualitatif, seperti kebiasaan, norma, kepercayaan, karakteristik, perasaan, emosi, spiritualitas, nilainilai, ideologi, dan budaya.

g. Shape (S), shape mengacu pada bentuk, performa, dan sifat visual dan fisik dari suatu obyek, yang termasuk didalamnya menganalisa tentang ukuran dan proporsi.

Bagan transformasi budaya tradisi metode ATUMICS dapat dilihat pada Gambar 4. Melalui metode ATUMICS yang diperlihatkan pada Gambar 4 , sebuah produk budaya dapat dilihat dari dua level utama tingkat keberadaannya yaitu level mikro dan level makro. Level mikro lebih berkaitan dengan sifat teknis dan penampilan produk. Produk dianalisis untuk didapatkan susunan ideal dari enam elemen dasarnya, yaitu teknik (Technique), kegunaan (Utility), bahan (Material), ikon (Icon), konsep (Concept), dan bentuk (Shape). Level makro berkaitan dengan aspek-aspek yang lebih luas, yaitu semangat dan motivasi dibalik produk yang dihasilkan. Hal ini terkait dengan bagaimana menemukan keseimbangan yang tepat di antara beberapa aspek yang berbeda, diantaranya budaya, sosial, ekologi, ekonomi, kelangsungan hidup, atau ekspresi diri dalam pembuatan sebuah produk. Di dalam konsep metode ATUMICS ini, perancangan sebuah produk harus menyatukan kedua level tersebut, level mikro dan level makro.

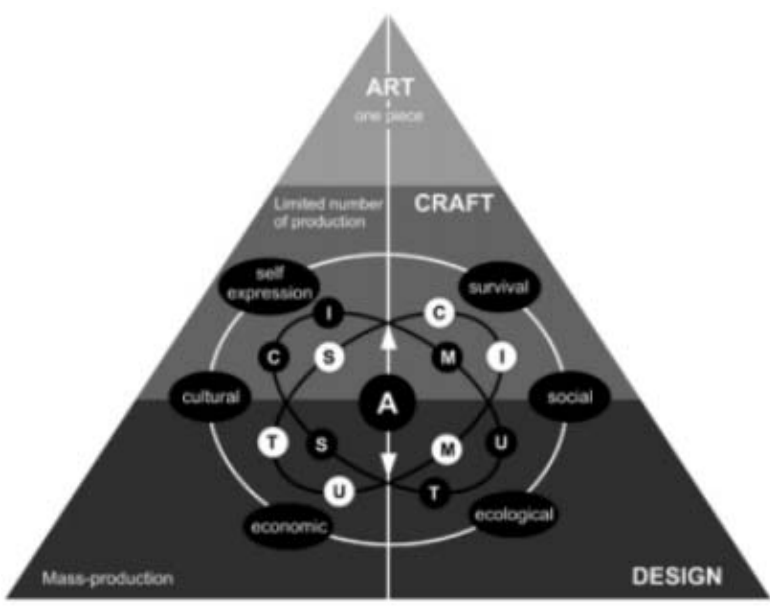

Gambar 4. Bagan transformasi budaya tradisi metode ATUMICS

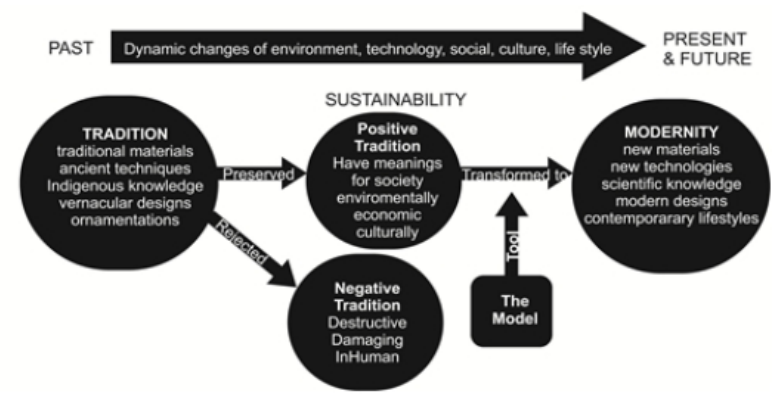

Gambar 5. Diagram Konsep Transformation of Tradition (Nugraha, 2012) 


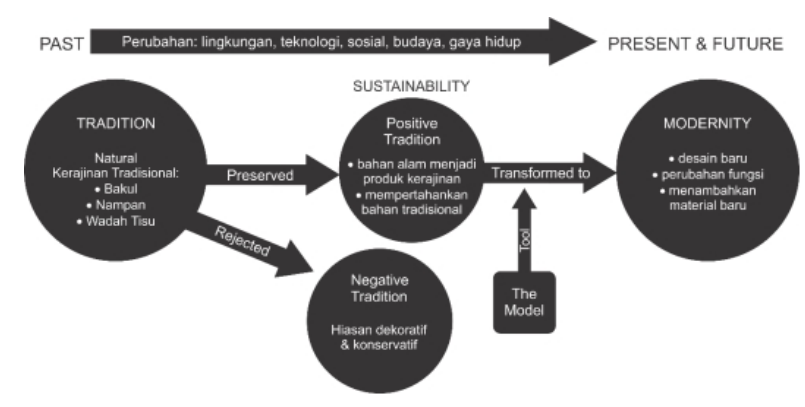

Gambar 6. Penerapan Diagram Konsep Transformation of Tradition (Merujuk pada Nugraha, 2012)

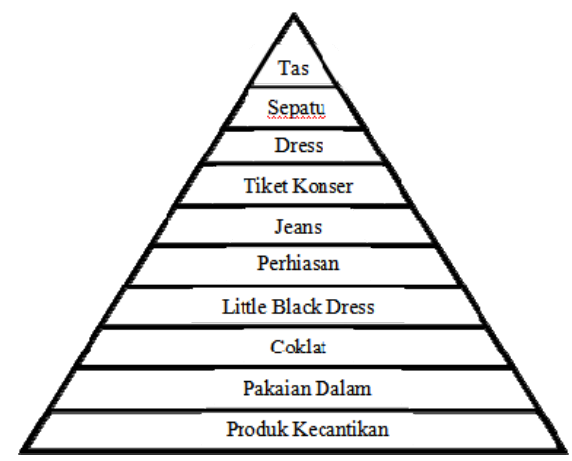

Gambar 7. Bagan 10 Benda yang disukai wanita

Penelitian menggunakan teori Transforming Tradition yang dikembangkan Adhi Nugraha dikembangkan dalam rangka upaya memelihara tradisi yang diaplikasi dalam konteks desain. Metode ini digunakan untuk mengkombinasikan beberapa elemen budaya tradisi dengan beberapa elemen budaya modern pada sebuah desain produk. Diagram Konsep Transformation of Tradition dapat dilihat pada Gambar 5.

Metode ini dipilih untuk digunakan untuk melakukan seleksi kekurangan dari tradisi yang ada agar kemudian ditutupi dengan kelebihan supaya tradisi tersebut dapat beradaptasi sesuai era modern (Harjani, 2017). Penerapan Diagram Konsep Transformation of Tradition dapat dilihat pada Gambar 6.

\section{Pengguna}

Menurut Japarianto dan Sugiharto (2011), Shopping Lifestyle menunjukkan cara seseorang mengalokasikan pendapatannya, seperti dari segi dana untuk berbagai alternatif preferensinya. Shopping Lifestyle terbentuk dari adanya keinginan konsumen untuk memenuhi kebutuhan maupun keinginannya.

Dalam memenuhi Shopping Lifestyle konsumen, banyak produsen yang harus memperhatikan segmen pasar yang dituju. Menurut Kotler dan Amstrong (2003), segmentasi pasar adalah melakukan pembagian pasar dari heterogen menjadi homogen yang disebabkan oleh adanya perbedaan kebiasaan membeli, kebutuhan pemakaian, penggunaan barang yang dibeli, dan motif atau tujuan ketika membeli. Dalam hal ini, wanita merupakan konsumen potensial yang cukup banyak menjadi sasaran para produsen untuk menawarkan produk-produknya (Sumarwan, 2011). Banyak wanita yang menjadikan fashion sebagai bagian penting penampilan hari-harinya. Selain pakaian, tas juga menjadi salah satu produk pelengkap fashion yang tidak bisa lepas dari seorang wanita.

Tas merupakan salah satu produk yang paling dicari wanita ketika berada dipusat perbelanjaan. Antusias wanita terhadap tas menjadi jembatan keinginan untuk menampilkan sisi feminisme dan jati dirinya. Menurut survei yang dilakukkan oleh situs aplikasi belanja di Inggris, Saveme4later.com, untuk menandakan peluncuran aplikasi belanja yang bisa membuat konsumen menyimpan iklan produk favoritnya sehingga konsumen tidak akan lupa soal produk tersebut saat memang ingin membelinya, diikuti oleh 2.000 wanita. Dari survei tersebut diketahui 10 benda yang paling disukai wanita untuk dibeli dapat dilihat pada Gambar 7. Survei tersebut menunjukkan bahwa tingkat antusiasme wanita paling tinggi ada pada produk tas. Tas bagi seorang wanita merupakan citra diri yang mampu menunjang penampilannya didepan umum.

\section{Hasil dan pembahasan}

Perbandingan produk sejenis antara produk tradisional dan produk modern diperlukan untuk melihat perkembangan produk serupa. Contoh produk tradisional dan produk modern dapat dilihat pada Gambar 8.

Berdasarkan gambar perbandingan dapat disimpulkan bahwa produk modern yang decorative memiliki banyak unsur warna yang membuat produk tidak terkesan eksklusif, sedangkan produk modern yang minimalis memiliki pepaduan warna dan ornamen yang minim.

Seperti halnya produk modern yang decorative, untuk produk tradisional yang decorative memiliki perpaduan warna dan ornamen hiasan tambahan yang banyak, serta beberapa memiliki motif dengan warna yang beragam pula. Sedangkan untuk produk tradisional minimalis, memiliki warna yang cenderung mempertahankan warna asli dari bahan. Meskipun memiliki tambahan dari bahan lainnya, 
Widya Christa Turang, Daniel Alexander Octavianus Turang Pengembangan desain tas wanita berbahan rumput Purun menggunakan metode ATUMICS

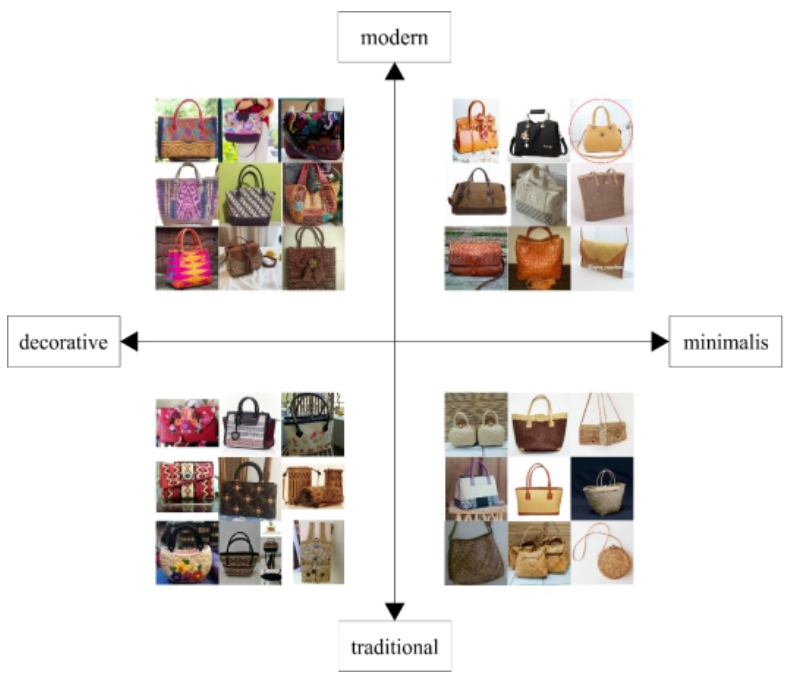

Gambar 8. Perbandingan Tas Tradisional dan Modern

produk tradisional minimalis menggunakan satu warna dan ornament yang ditambahkan sesuai dengan fungsi yang dibutuhkan produk.

Pada diagram perbandingan di Gambar 8, terdapat produk pilihan dengan ditandai lingkar merah. Produk tas tersebut merupakan produk yang akan menjadi acuan desain pada produk Purun yang dikembangkan. Produk yang dipilih merupakan produk modern yang minimalis.

\section{Aspek desain dalam ATUMICS}

Melestarikan budaya tradisi dapat dilakukan dengan mentransformasikan budaya tradisi ke dalam budaya modern (Nugraha, 2012). Salah satunya adalah dengan metode ATUMICS. Prinsip utama metode ATUMICS adalah tentang pengaturan, kombinasi, integrasi, atau campuran antara unsurunsur dasar tradisi dengan modernitas. Metode ini digunakan untuk mengkombinasikan beberapa elemen budaya tradisi dengan beberapa elemen budaya modern pada sebuah desain produk. Analisa anyaman Purun dengan metode ATUMICS dapat dilihat pada Tabel 1. Perbandingan Anyaman Purun dengan Produk Tas Modern dapat dilihat pada Tabel 2.

Berdasarkan analisa ATUMICS dan perbandingan antara anyaman Purun dengan produk tas modern diatas, dapat diidentifikasikan potensi dalam mendesain objek baru, yaitu:

a. Elemen yang bisa dipertahankan: (1) Menggunakan bahan Purun; (2) Teknik pembuatan menggunakan motif Anyaman Tunggal.

b. Elemen yang dapat diubah: (1) Bentuk diubah menjadi produk berbentuk seperti balok; (2) Fungsi dari produk sebagai sarana bawa yang mobile dan digunakan untuk membawa barang ringan saat
Tabel 1. Analisa anyaman Purun dengan metode ATUMICS

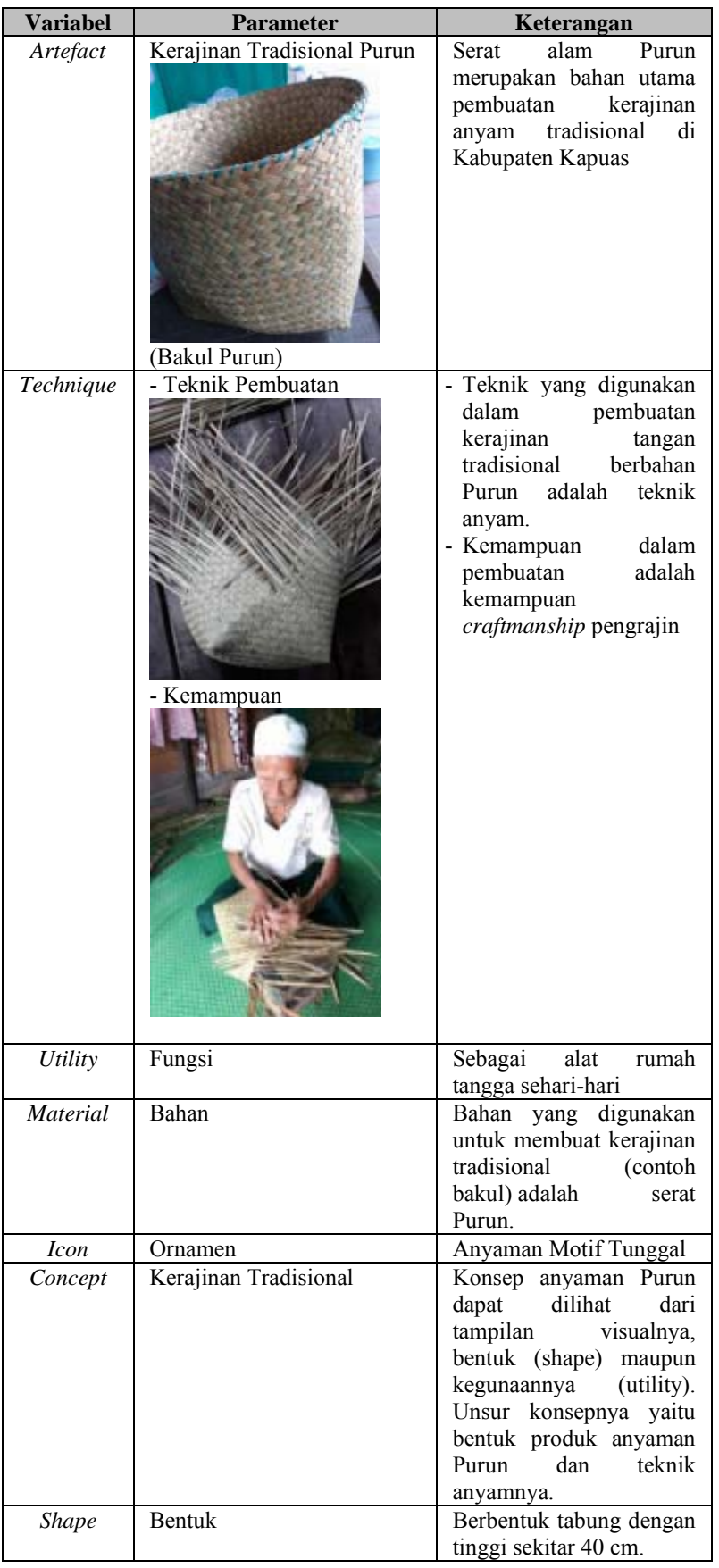

bepergian; (3) Konsep tidak lagi sebagai produk kerajinan tradisional melainkan produk penunjang fashion wanita.

c. Elemen yang dihilangkan: material tali rafia atau hiasan dekoratif.

d. Elemen yang ditambahkan: (1) Penambahan bahan pendukung berupa kulit sintetis yang digunakan sebagai tali yang berfungsi sebagai bagian saat membawa produk; (2) Menambahkan logam 
aksesoris sebagai penyambung tali dengan bagian tas; (3) Menambah aksesoris kancing sebagai kuncian di bagian depan tas.

Berdasarkan permasalahan desain yang ada, maka dibutuhkan pengembangan desain kerajinan Purun sebagai berikut: (1) Produk memiliki inovasi desain dari produk kerajinan tradisional; (2) Produk mampu meningkatkan harga jual; (3) Produk dapat menarik pasar dari kalangan muda; (4) Penggunaan tambahan bahan pendukung yang mudah didapat; (5) Proses pengerjaan produk dilakukan oleh pengrajin Purun dengan kemampuan craftmanship.

Sedangkan Positioning product dari kerajinan Purun, meliputi: (1) Target pengguna (kalangan anak muda); (2) Gender (perempuan); (3) Usia (17 tahun keatas); (4) Kelas Sosial (semua kalangan); (5) Segmentasi (masyarakat wilayah Kalimantan Tengah dan di luar Kalimantan Tengah); (5) Penggunaan (digunakan untuk membawa barang saat berpergian)

Berdasarkan Image board pada Gambar 9, kesan yang ingin dimunculkan dalam produk yaitu: (1) Produk berupa tas dengan warna earth tone; (2) Produk menggunakan teknik anyaman; (3) Bentuk produk minimalist dan bertekstur; (4) Produk cocok dipadukan sebagai bohemian style, chic style, maupun feminine dan semiformal style; (5) Produk ditujukan untuk remaja wanita, pegawai kantor, dan fashion enthusiast; (6) Produk dapat digunakan untuk membawa barang ringan seperti dompet, handphone, atau beberapa kosmetik sehari-hari; (7) Produk digunakan dengan cara dijinjing atau diselempangkan.

Produk dibuat berukuran kecil agar dapat digunakan saat bepergian ke pusat perbelanjaan, cafe atau restoran, maupun ke sebuah acara. Tas Purun memiliki lapisan tas bagian dalam yang dibuat terpisah atau tidak digabungkan dengan bahan utamanya sebagai inovasi pada produk ini. Lapisan tas ini dibuat dengan ukuran yang hampir sama dengan ukuran tas, dan terdapat serutan dibagian atas lapisan tas yang berfungsi untuk mengunci tas agar barang di bagian dalam tidak terjatuh.

Produk Tas Purun ini memiliki bentuk persegi panjang dengan ukuran $28 \times 10 \times 20 \mathrm{~cm}$. Terdapat bagian lapisan tas atau furing yang didesain terpisah dari tas berbentuk seperti pouch atau dompet dengan penutup atas yang dapat diserut saat ingin ditutup. Selain itu, dibagian depan tas terdapat kancing yang berfungsi untuk menahan pouch atau dompet bagian atas tas yang terbuka.

Pada bagian atas tas terdapat dua tali untuk membawa tas yaitu tali berukuran pendek yang digunakan dengan cara dijinjing, dan pada sisi samping tas tali berukuran panjang yang digunakan dengan cara diselempangkan. Tali-tali yang terdapat pada tas Purun ini menggunakan bahan tambahan berupa kulit sintetis untuk menambah kesan eksklusif pada produk. Tali jinjing diberi logam aksesoris yang berfungsi agar tali tersebut dapat lebih mudah diatur posisi keatas saat dijinjing dan kebawah saat menggunakan tali panjang. Untuk tali panjang sisi samping tas terdapat pengait logam aksesoris berwarna emas untuk melepas-pasang tali sesuai kebutuhan pemakaian tas. Render desain bagian luar tas dan bagian dalam tas dapat dilihat pada Gambar 10.

Tabel 2. Perbandingan Anyaman Purun dengan Produk Tas Modern

\begin{tabular}{|c|c|c|}
\hline Artefak & Tradisional & Modern \\
\hline Technique & $\begin{array}{lr}\text { - Teknik yang } & \text { digunakan } \\
\text { dalam } & \text { pembuatan } \\
\text { kerajinan } & \text { tangan } \\
\text { tradisional } & \text { berbahan } \\
\text { Purun adalah } & \text { teknik } \\
\text { anyam. } & \\
\text { - Kemampuan } & \text { dalam } \\
\text { pembuatan } & \text { adalah } \\
\text { kemampuan } & \\
\text { craftmanship pengrajin. }\end{array}$ & $\begin{array}{lr}\text { - Teknik } & \text { yang } \\
\text { digunakan } & \text { dalam } \\
\text { pembuatan } & \text { produk } \\
\text { menggunakan } & \text { teknik } \\
\text { anyam dan } & \text { teknik } \\
\text { jahit. } & \\
\text { - Kemampuan } & \text { dalam } \\
\text { pembuatan } & \text { adalah } \\
\text { kemampuan } & \\
\text { craftmanship } & \\
\text { pengrajin. } & \end{array}$ \\
\hline Utility & $\begin{array}{l}\text { - Sebagai alat dalam } \\
\text { rumah tangga. }\end{array}$ & $\begin{array}{l}\text { - Sebagai sarana bawa } \\
\text { yang mobile. } \\
\text { - Sebagai sarana } \\
\text { membawa barang } \\
\text { ringan. }\end{array}$ \\
\hline Material & $\begin{array}{l}\text { - Menggunakan bahan } \\
\text { Purun sebagai bahan } \\
\text { utama } \\
\text { - Menggunakan bahan tali } \\
\text { rafia dan hiasan dekoratif } \\
\text { \& konservatif }\end{array}$ & $\begin{array}{l}\text { - Menggunakan bahan } \\
\text { Purun yang } \\
\text { dikombinasi dengan } \\
\text { bahan pendukung } \\
\text { lain. } \\
\text { - Menggunakan bahan } \\
\text { tambahan aksesoris } \\
\text { yang sesuai. }\end{array}$ \\
\hline Icon & $\begin{array}{l}\text { - Menggunakan motif } \\
\text { anyaman biku-biku \& } \\
\text { anyaman tunggal. }\end{array}$ & $\begin{array}{l}\text { - Menggunakan motif } \\
\text { anyaman tunggal. }\end{array}$ \\
\hline Concept & $\begin{array}{l}\text { - Sebagai } \\
\text { tradisional. }\end{array}$ & $\begin{array}{l}\text { - Sebagai penunjang } \\
\text { fashion wanita. }\end{array}$ \\
\hline Shape & $\begin{array}{cr}\text { - Memiliki } & \text { bentuk } \\
\text { menyerupai } & \text { tabung } \\
\text { dengan berbagai ukuran. }\end{array}$ & $\begin{array}{l}\text { - Memiliki bentuk } \\
\text { yang bervariasi. }\end{array}$ \\
\hline
\end{tabular}

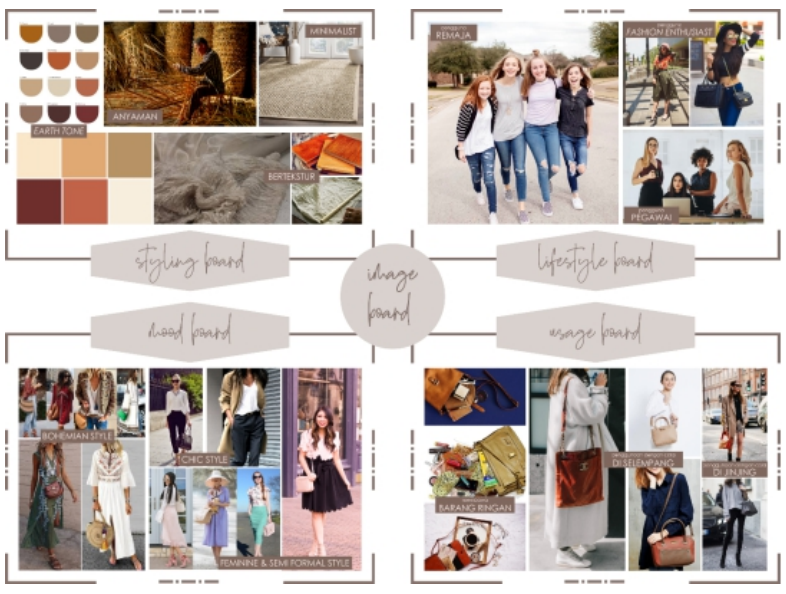

Gambar 9. Image Board 


\section{Branding}

Purun merupakan salah satu bahan alam di Kalimantan Tengah yang dijadikan sebagai bahan utama pembuatan produk. Suku asli dari Kalimantan Tengah adalah Suku Dayak, dengan mayoritas penduduknya merupakan Suku Dayak Ngaju. Oleh karena itu, produk ini akan diberi brand "Ayun Itah".

Ayun Itah adalah kata dari Bahasa Dayak Ngaju, dimana bahasa tersebut adalah bahasa daerah yang sangat kental di suku Dayak Kalimantan Tengah. Ayun Itah memiliki arti Milik Kita. Pada bagian atas desain huruf A di kata Ayun, terdapat gambar ikat kepala Khas Suku Dayak Ngaju yaitu Lawung. Lawung merupakan ikat kepala khas Suku Dayak Ngaju di Kalimantan Tengah yang menyimbolkan mahkota para tokoh adat Dayak. Dengan demikian, diharapkan masyarakat yang memakainya memiliki "rasa memiliki" pada produk yang berasal dari salah satu bahan alam di Provinsi Kalimantan Tengah ini. Logo yang digunakan sebagai branding dapat dilihat pada Gambar 11.

\section{Proses Perwujudan Desain}

Pembuatan produk dimulai dengan menyiapkan Purun yang sudah melalui proses penumbukkan dan pengeringan. Purun dipilah yang terbaik guna mendapatkan hasil anyaman yang bagus. Lembaran Purun dapat dilihat pada Gambar 12 (kiri). Kemudian Purun pilihan ini mulai dianyam satu persatu. Proses pengayaman Purun dapat dilihat pada Gambar 12 (kanan), dan hasil anyaman yang sudah selesai dapat dilihat pada Gambar 12 (bawah).

Menyesuaikan bentuk tas sesuai dengan sketsa desain maka Purun dianyam perlembar pola yang kemudian nanti disatukan dengan teknik jahit manual. Membentuk tas sesuai desain, maka lembaran pola anyaman Purun yang sudah disesuaikan dengan ukuran perbagiannya, disatukan sesuai bentuk menggunakan teknik jahit manual memakai tali korea.

Setelah pola tas selesai disatukan dan membentuk badan tas, kemudian dilakukan pemasangan kancing berwarna coklat tembaga dengan diameter $5 \mathrm{~cm}$ dibagian depan. Kancing ini selain berfungsi sebagai pengunci bagian atas tas tapi juga sebagai ornamen yang mempercantik tampilan tas. Di bagian belakang tas, dipasang tali yang sudah dikepang kecil sebagai tali pengait pada kancing. Pola tas yang telah disatukan dengan teknik anyam dapat dilihat pada Gambar 13 (atas).

Setelah bentuk tas selesai disatukan, selanjutnya masuk pada tahap membuat bagian tali sebagai bagian dari tas. Tali tas dibuat menggunakan bahan pendukung berupa kulit sintetis. Tali tas terdiri dari dua bagian berbeda yaitu tali sisi depan dan belakang tas dengan ukuran pendek, dan tali panjang di sisi samping tas.

Bagian dalam tas tentu umumnya terdapat lapisan berupa kain furing. Namun untuk tas Purun ini didesain dengan bagian dalam tidak menggunakan kain furing, melainkan diganti menggunakan kain goni. Kain goni dijahit berbentuk seperti pouch atau dompet dengan penutup atas menggunakan tali goni yang dapat diserut saat ingin ditutup. Bagian dalam tas ini diinovasi dengan tidak dibuat menempel dengan bagian tas Purun. Bentuk bagian dalam tas dapat dilihat pada Gambar 13 (bawah). Hasil akhir dari produk tas dapat dilihat pada Gambar 14.

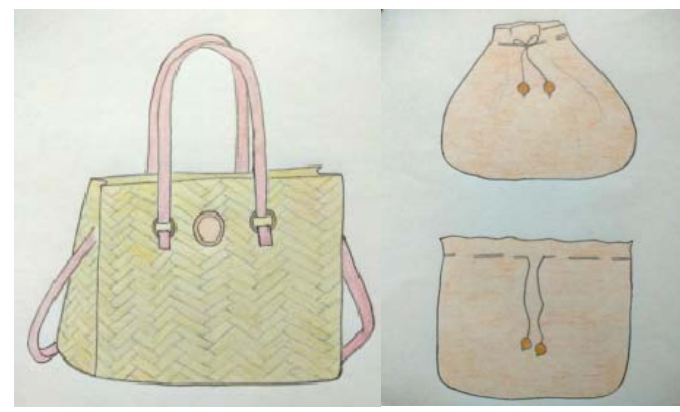

Gambar 10. Render desain bagian luar tas (kiri) dan Bagian dalam tas (kanan)

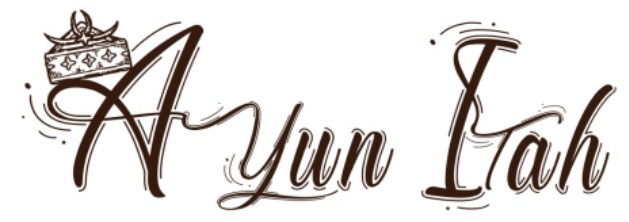

Gambar 11. Logo

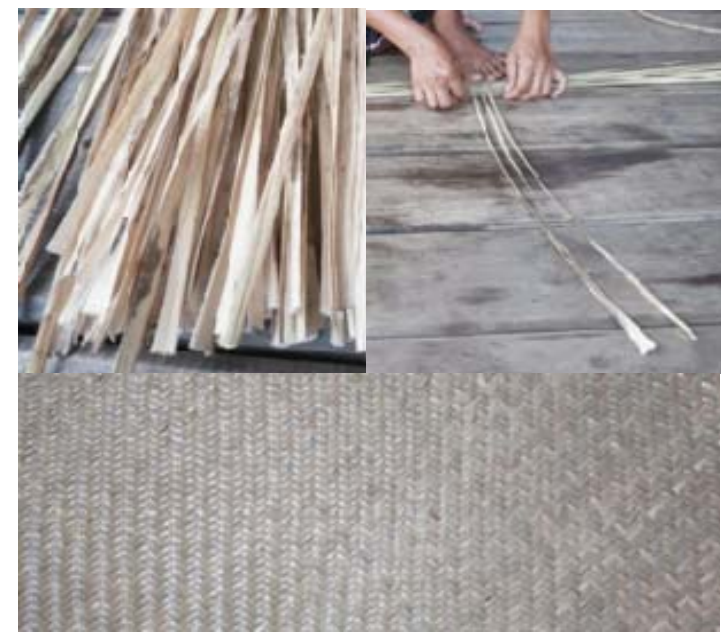

Gambar 12. Lembaran Purun (kiri), Purun mulai dianyam (kanan), dan hasil anyaman Purun (bawah) 


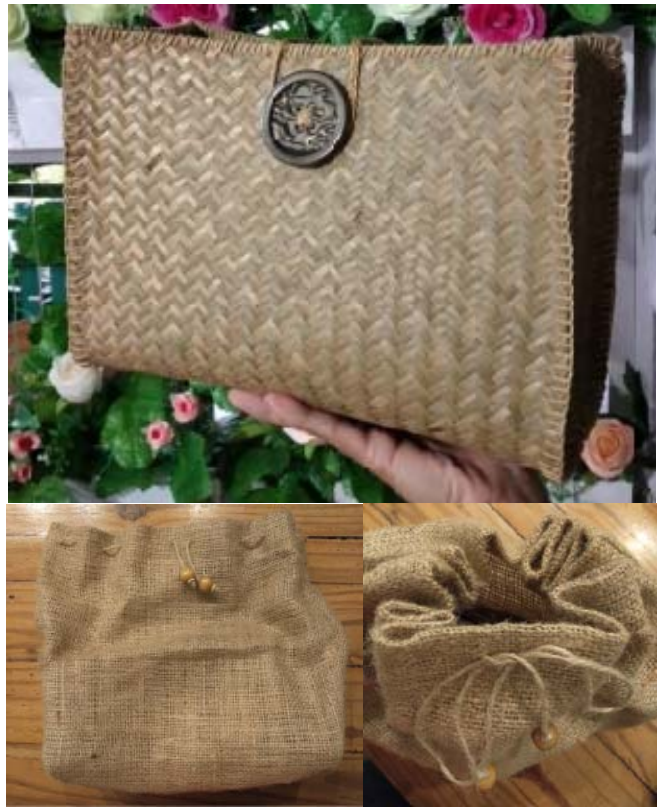

Gambar 13. Tas yang sudah disatukan polanya (atas), bentuk pouch terbuka (kiri bawah) dan bentuk pouch bagian atas di serut (kanan bawah)

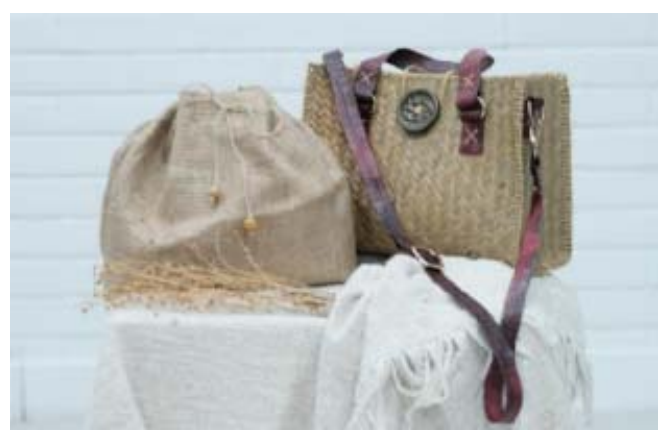

Gambar 14. Hasil Akhir Produk

\section{Kesimpulan}

Berdasarkan hasil penelitian pengembangan desain tas wanita dan pemecahan masalah melalui produk, maka dapat disimpulkan bahwa produk Purun yang dikembangkan menjadi salah satu fashion wanita mampu menambah penghasilan pengrajin Purun. Desain yang minimalis dengan aksesoris tambahan yang disesuaikan dengan kebutuhan pada tas dan perpaduan yang tepat digemari oleh masyarakat. Pengembangan Purun menjadi produk fashion wanita berupa tas dengan konsep minimalis modern mampu mengenalkan bahan Purun di kalangan muda. Dalam pengembangan produk, teknik anyam dapat dipertahankan sebagai ciri utama dalam produk.

\section{Daftar pustaka}

Asikin, S., Thamrin, M., \& Budiman, A. (2001). Purun tikus Eleocharis dulcis (Burm. F.) Henschell sebagai agensia pengendali hama penggerek batang padi putih dan konservasi musuh alami di lahan rawa pasang surut. Prosiding Simposium Keanekaragaman Hayati dan Sistem Produksi Pertanian, Perhimpunan Entomologi Indonesia.

Asikin, S., \& Thamrin, M. (2011). Penggerek batang padi putih dan pengendaliannya di lahan pasang surut. Seminar Nasional Perhimpunan Entomologi Indonesia. Universitas Padjadjaran Bandung.

Brecht, J. K. (1998). Waterchesnut. Horticultural Sciences Department, University of Florida.

Brewer, J. D. (2000). Ethnography. UK : McGraw-Hill Education.

Budiman, A., Thamrin, M., \& Asikin, S. (1988). Beberapa jenis gulma di lahan pasang surut Kalimantan Selatan dan Tengah dengan tingkat kemasaman tanah yang berbeda. Prosiding Konferensi IX HIGI.

Gerbono, A., \& Djarijah, A. S. (2005). Aneka Anyaman Bambu. Yogyakarta: Kanisius.

Harjani, C. (2017). Penerapan Canang Sesaji Ritual Bali Pada Perlengkapan Di Ruang Makan. Yogyakarta: Pasca Sarjana ISI.

Japarianto, E., \& Sugiharto, S.. (2011). Pengaruh Shopping Lifestyle dan Fashion Involvement Terhadap Impulse Buying Behavior Masyarakat High Income Surabaya. Jurnal Management Pemasaran 6(1), pp. 1-24.

KBBI. (2018). Kamus Besar Bahasa Indonesia (KBBI). [Online] Available at: http://kbbi.web.id/, [Diakses 1 Desember 2019].

Kotler, P., \& Armstrong, G. (2003). Dasar-dasar Pemasaran, Jilid 1, Edisi Kesembilan, Jakarta : PT. Indeks Gramedia.

Maulana, A. E. (2009). Consumer Insight Via Etnography. Jakarta: Penerbit Erlangga.

Mutmainah, S. (2014). Buku Ajar: Kriya Anyam. Surabaya: Jurusan Seni Rupa Fakultas Bahasa dan Seni UNESA.

Nugraha, A. (2012). Transforming Tradition: A Method for Maintaining Tradition in a Craft and Design Context. Helsinki: Aalto University, School of Arts, Design and Architecture, Finland.

Raharjo, B. (2011). Seni Kerajinan Pandan. Klaten: PT. Macanan Jaya.

Shaifuddin, M. (2009). Pengantar Pendidikan Seni Rupa Anak. Salatiga : Widya Sari Press Salatiga.

Sumanto. (2005). Pengembangan Kreativitas Seni Rupa Anak TK. Jakarta: Depdiknas.

Sumarwan, U., (2011). Perilaku Konsumen (Teori dan Penerapannya dalam Pemasaran). Edisi ke 2. Bogor : PT Ghalia Indonesia.

Van Steenis, C. G. G. J. (2006). Flora. Jakarta : Pradnya Paramitha.

Wahudi, S., \& Darmowiyoto, M. (1979). Pengetahuan Teknologi Kerajinan Anyam. Jakarta: DEPDIKBUD.

Wihardi, S. J. F. R. (1979). Catatan Sedehana Anyaman Bambu dan Rotan. Yogyakarta: Balai Besar Penelitian dan Pengembangan Industri Kerajinan dan Batik.

Zain, S. M. (1992). Kamus Indonesia Modern. Jakarta PN: Grafika.

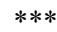

